\title{
Indo-Roman trade: the ceramic evidence from Egypt
}

\author{
ROBERTA TOMBER*
}

\begin{abstract}
Sourcing studies of the ceramics found at Roman Berenike on the Red Sea of Egypt show that India or the neighbouring regions supplied many styles and types of pottery.
\end{abstract}

Key-words: Egypt, Roman, Berenike, ceramics, sourcing studies, trade

\section{Introduction}

The Egyptian Red Sea site of Berenike has long been recognized as a port of foremost importance for the trade between Egypt, Arabia and India. Established by Ptolemy in the mid-3rd century $\mathrm{BC}$ and operational, at differing levels through time, until the early 6th century AD, Berenike's role in long-distance trade is known through historical documents, most explicitly from the 1st-century Periplus Maris Erythraei (Casson 1991: 8) and the Nicanor archive $(O$. Tait P220-304/Tait 1930-64; Fuks 1951). The former, dated to the mid 1st century, provides a detailed practical account of the ports and goods in the Red Sea, Gulf of Aden and the western Indian Ocean for traders in Roman Egypt; while the latter, spanning the period between 6 BC-AD 68/69, comprises a group of receipts from a family shipping firm operating between Coptos on the Nile to the Red Sea ports of Berenike and Myos Hormos (see FIGURE 1 for location map).

Excavations undertaken at Berenike since 1994, by Steve Sidebotham and Willeke Wendrich (Sidebotham \& Wendrich 1995; 1996; 1998; 1999; in press), have provided tangible archaeological evidence for Indo-Roman trade from a broad spectrum of artefacts, including ceramics, glass beads (Francis in press), textiles (Wild \& Wild in press), as well as archaeobotanical remains (seeds, Cappers 1996: 330-31; 1998: 311-19; and wood, Vermeeren 1998: 347) and epigraphic evidence from a single TamilBrahmi graffito (Mahadevan 1996). This note concentrates on the pottery, in order to draw attention to the range and quantity of material recovered from Berenike with links to India or South Asia, and highlights the scope for future analytical work to refine the source areas of these vessels. The pottery is of interest not only for confirming contact between the two regions, but, in conjunction with other classes of artefacts, investigating the nature of this contact and the traders involved. Because of its context, in association with well-dated Roman material, it also complements the dating evidence from the Indian finds. Most, but certainly not all, of the sherds come from early Roman deposits of either late Augustan or mid/late 1stcentury AD date; those which occur in late Roman deposits are more difficult to judge since many of these contexts contain a high proportion of residual wares, but evidence from the beads indicates flourishing contact between Egypt and Sri Lanka during the late Roman period (Francis in press). More detailed descriptions of the Berenike sherds, particularly the fabrics, can be found elsewhere (Begley \& Tomber 1999; Tomber \& Begley in press). This note draws heavily on the evidence from Arikamedu, where both forms (FIGURE 2) and fabrics are well published (Wheeler et al. 1946; Begley 1996b), although increasingly new evidence for many ceramic types and interaction between the regions is available from Sri Lanka (e.g. Coningham \& Allchin 1995) and Southeast Asia (e.g. Ardika \& Bellwood 1991).

\section{Table wares}

Table wares are sparsely represented but include vessels which are unequivocally Indian in origin. Included in this category are dishes with in-turned beaked rims (Wheeler et al. 1946: Type 1/Begley 1996b: Form 1), belonging to what is commonly known as 'rouletted' ware, due to their bands of 'chattered' decoration on the

\footnotetext{
* Museum of London Specialist Services, 46 Eagle Wharf Road, London N1 7ED, England. rtomber@museumoflondon.org.uk
}

Received 10 Octobor 1999, accepted 4 February 2000, revised 16 May 2000.

ANTIQUITY 74 (2000): 624-31 


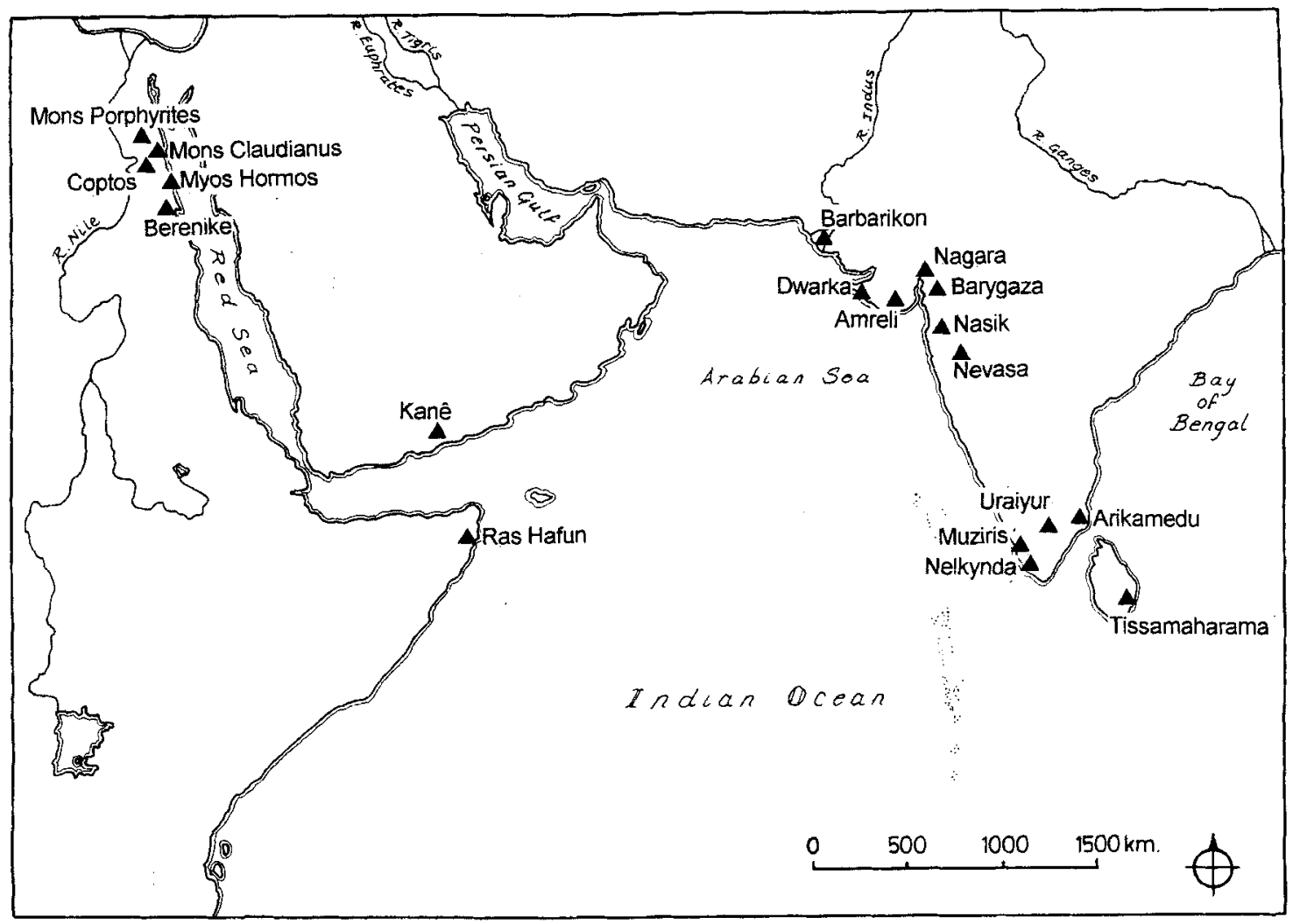

FIGURE 1. Location map of the region and sites mentioned in the text.

base (Ardika et al. 1993; Begley 1988). A minimum of six vessels of this type was recovered from the 1997-8 excavations (FIGURE 2.1; FIGURE $3)$. Four of these occur in a nearly inclusionless, micaceous fabric with good quality glossy slip that can be equated with Arikamedu Fine Ware 1, with the remaining two in a coarser, sandy paste, possibly related to Arikamedu Coarse Ware 1A.

Another table ware represented at Berenike is the small bowl or cup, decorated with bands of parallel incised lines, between which stamped animal motifs are sometimes placed (Wheeler et al. 1946: Type 10/Begley 1996b: Form 5). While stamps are absent on the two vessels represented by rims at Berenike (e.g. FIGURE 2.2 ), one does bear a shallow depression which may have been intended as a stamp: nevertheless, vessels are known in India without the stamp. In addition to these two vessels, a further two are indicated by base and body sherds. Three of these bowls are in the classic Arikamedu Fine Ware 1 fabric, while the fourth is in a related one of slightly poorer quality.

In South Asia the distribution of rouletted ware, paralleled by much smaller quantities of Wheeler 10, is biased although not restricted to the eastern coast of India and the western coast of Sri Lanka (see Begley 1996b: figure 1.12; Silva 1985), although recently a more widespread distribution is known from Sri Lanka (Coningham \& Allchin 1995). No production sites have been located, but Gogte (1997) has proposed the Ganges delta as the source area for these vessels.

\section{Utilitarian wares}

This group vastly outnumbers table wares in quantity, but their source identification is more problematic. The most common amongst these are cooking wares which are morphologically identical to Indian forms, utilize a similar but not identical technology and range of fabrics and, as a corollary, are distinct from Egyptian forms and fabrics. The forms identified at 

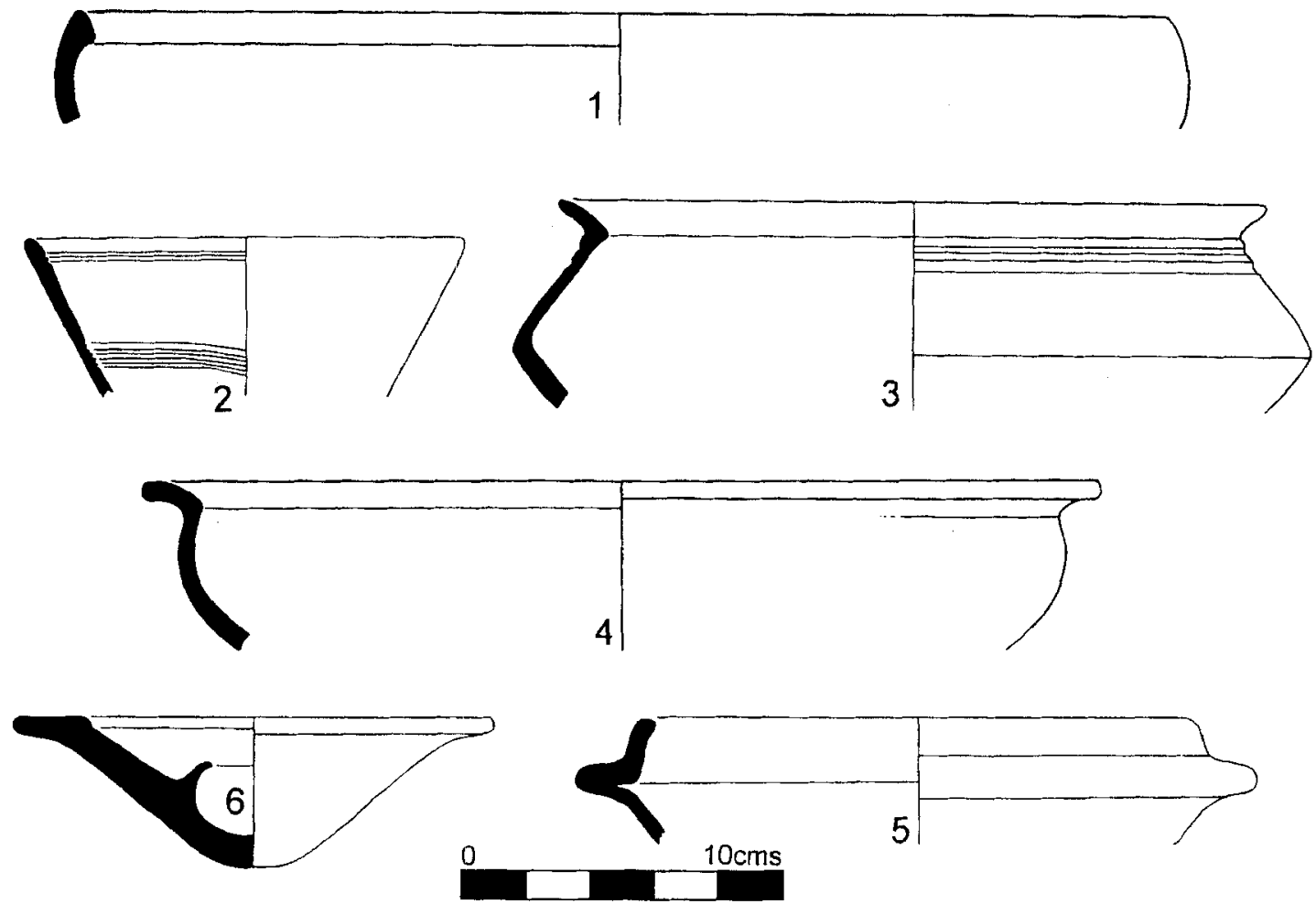

FIGURE 2. Indian and Indian-style pottery types from Berenike.

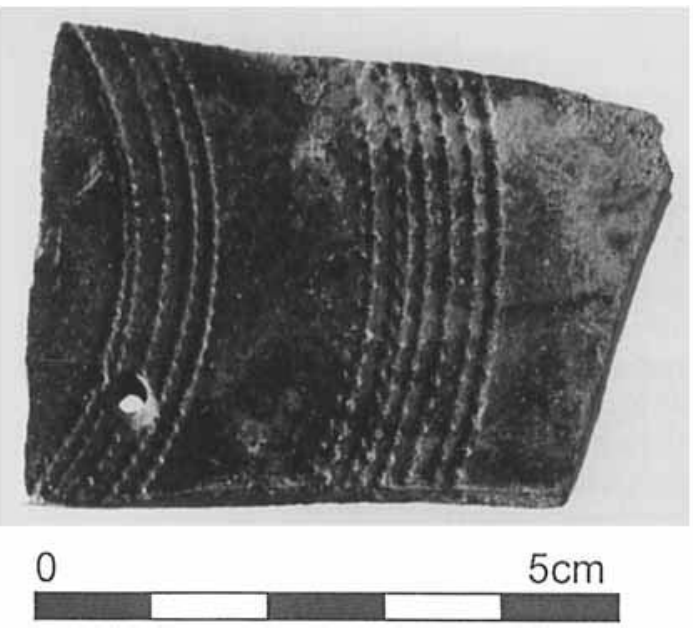

FIGURE 3. 'Rouletted' decoration on a Wheeler Type 1 dish from Berenike.

Berenike occur both at Arikamedu and at numerous other sites in India both during the period in question (subsumed within the In- dian 'Early Historic') and the medieval period. The vessels are cooking pots with sharply everted rims and, frequently, carinated shoulders (Wheeler et al. 1946: Type 24; FIGURE 2.3); casseroles with over-turned rims (Wheeler et al. 1946: Type 25; FIGURE 2.4) and flanged casseroles or lids (Wheeler et al. 1946: Types 2829/Begley 1996b: Form 17; FIGURE 2.5). Although comprising a similar range of inclusions, unlike the finewares, their fabrics cannot be directly equated with ones present at Arikamedu (Begley \& Tomber 1999: 180) and their wide distribution means that an origin further afield, particularly in South Asia, remains a possibility.

Wheeler Types 24, 25, 28/29 excavated at Berenike are related in both fabric and surface treatment, comprising a sandy paste, frequently with burnished red slip covering the surfaces either entirely or in part. The sooted condition of many vessels leaves no doubt that they were used over an open fire. Despite being united by shape and surface treatment, closer examination of the clays indicates that more than one as yet unidentified source is represented. Body 


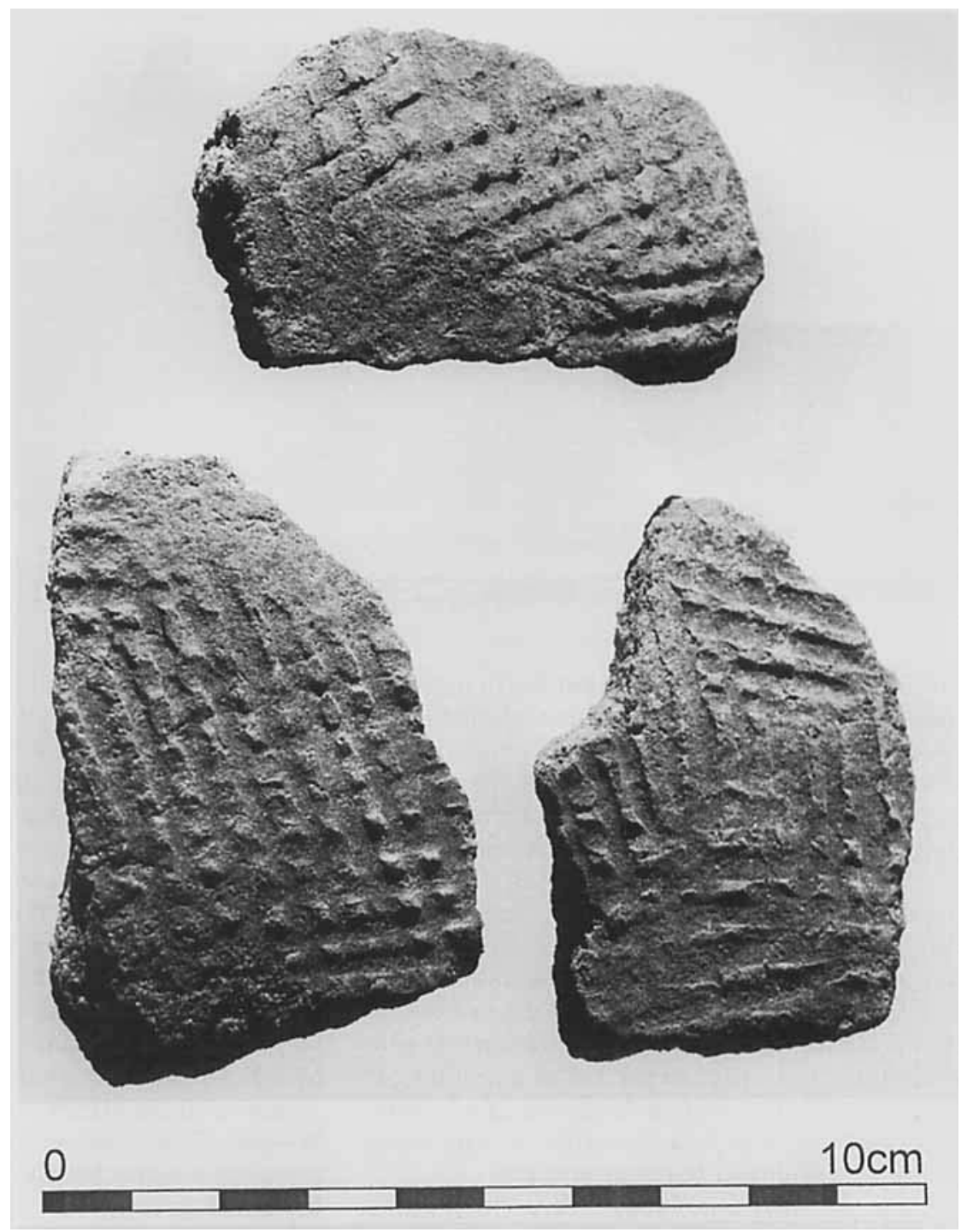

FIGURE 4. Paddleimpressed sherds from Berenike. sherds in similar fabrics, which in rare instances can be associated with these forms, frequently exhibit internal wiping marks which result from organic material. Modern potters are known to use bamboo tools for shaping and scraping during the manufacturing process (Saraswati \& Behura 1966: 28-31), and it is possible that these marks result from bamboo. Our vessels appear better finished than similar forms seen, for example, from sites in Maharashtra and Gujarat, and superficially more allied to the better-quality vessels from Arikamedu, despite fabric differences already noted. These obser- vations, however, are based on the macroscopic examination of a small sample of assemblages, including ones from Nevasa, Dwarka, Nasik, Amreli and Nagara, and do not allow a source area to be suggested for the Berenike vessels. Nevertheless, it is worth observing that the deep organic marks on our vessels were not seen on vessels from these sites, nor from the material excavated by Wheeler from Arikamedu.

Of the cooking vessels, Type 24 (FIGURE 2.3) is the most common, followed by Type 25 (FIGURE 2.4) and finally Types 28/29 (FIGURE 2.5). In aggregate they form between $1-9 \%$ of non- 


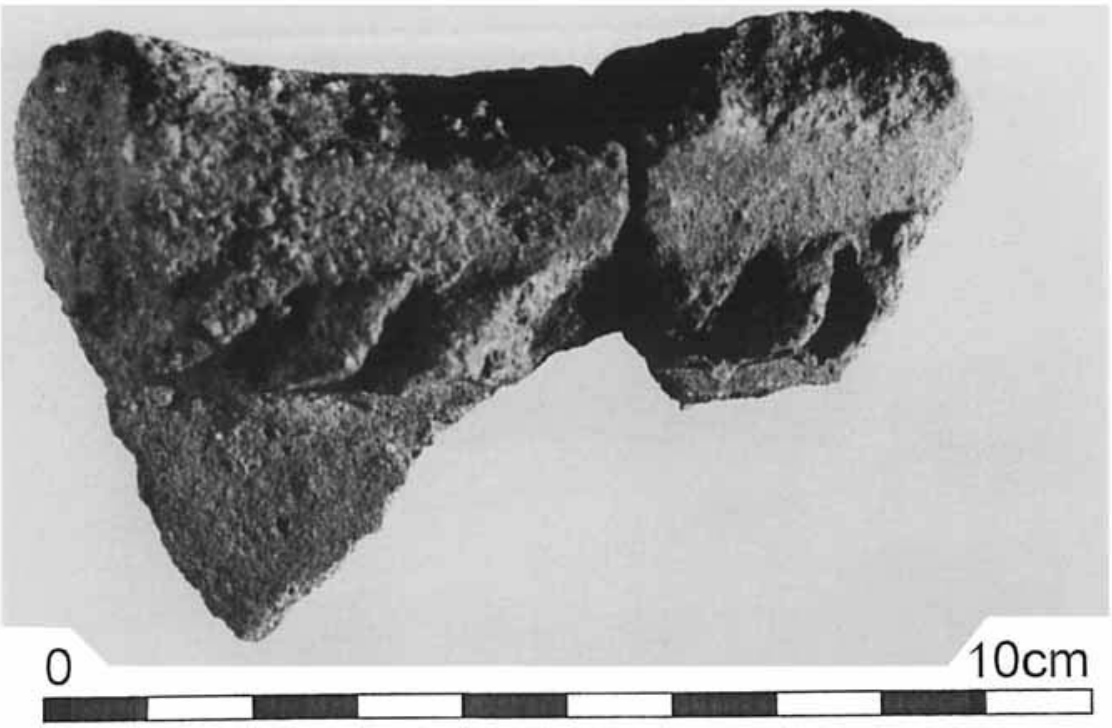

FIGURE 5. Berenike vessel decorated with slashed, applied strip. amphora sherds in large quantified early Roman deposits. Type 24 was also identified at Quseir al-Qadim on the Red Sea coast during the late 1970s (e.g. Johnson 1979: plates 22a (top), 25s, 31j), and David Peacock's new campaign at this site promises a much wider range of Indian-style pottery. Excavation of Roman deposits during the 2000 season included all three of these coarse-ware forms, in a similar fabric and with wiping marks like those found at Berenike (Tomber in press). Future excavation will provide further evidence from this site, which has been identified as the ancient port of Myos Hormos (Bülow-Jacobsen et al. 1994; Peacock 1993) and, like Berenike, is mentioned in the Periplus and Nicanor archive.

Another utilitarian form, Type 38 (FIGURE 2.6), described by Wheeler as a 'cup-and-saucer' shaped lid, is sometimes referred to as a lamp. The vessel from Berenike is sooted both on the inside and outside, adding little to its functional interpretation. Like the previous forms it has a widespread distribution within India, but closer to Berenike variants have been recorded by Smith \& Wright (1988: 136, figure 9 , i \& k) from Ras Hafun in Somalia, and by Sedov (1992: figure 3.6-7; 1996: figure 6.1112) from Kanê in the Yemen, who also notes its presence at early Christian sites along the Nile in Nubia (Sedov 1992: 114). From a poorly dated context, the Berenike vessel is likely to be 1st- or 2nd-century $\mathrm{AD}$; the Kanê pieces from its 'middle' period dated from the late 2nd to the 4th century AD; and at Ras Hafun from the 2nd to the 5th century AD; finally, in India the type is known from the 1st century AD into medieval times (Begley \& Tomber 1999: 171).

The Berenike fabric is crude and porous with poorly finished surfaces. At Ras Hafun, where the type is common, it occurs in a 'Limestone and Vegetal-tempered Red Fabric' (Smith \& Wright 1988: 122), which from published description alone seems similar to the Berenike fabric. The Ras Hafun vessels were examined by B.B. Lal, who equated them with vessels from western India (Henry Wright pers. comm.). Western India therefore remains the strongest possible source for the Berenike vessels, although more comparison of the fabrics is needed.

Large vessels externally decorated by grooved paddles constitute another substantial group - over 40 sherds - of potentially Indian pottery excavated from Berenike (FlGURE 4). A few sherds have now also been identified from Roman contexts at Quseir al-Qadim. The type was sparsely represented from Wheeler's excavations at Arikamedu, but a total of 874 were recovered from the 1991-2 excavations in a variety of fabrics, some of which are atypical and therefore probably non-local to Arikamedu (Begley 1996b: Motif 6; Selvakumar in press). In India the type has a fairly restricted eastern distribution where they occur from the 1st century $\mathrm{BC}$ into the 3rd or 4 th century $\mathrm{AD}$, are oc- 
casionally found in the medieval period and are produced by modern potters in Mysore, Andra Pradesh, Goa, Kerala, Madras and West Bengal (Begley 1996b: 202-4; Saraswati \& Behura 1966: 22). The coarse, sandy fabric of the Berenike sherds corresponds well with those from Arikamedu, and India is the most likely source for them. Nevertheless, other potential sources cannot be entirely ruled out in light of their presence elsewhere during this period, including Tissamaharama in Sri Lanka ( $\mathrm{H}$. Schenk-Weisshaar pers. comm.) and Southeast Asia (Begley 1996b: 204 note 10).

A final group of utilitarian vessels from Berenike with applied, thumbed or slashed strips are stylistically less distinct than the paddle grooved ones and have a more ubiquitous distribution, both in India and beyond, including sherds in a black fabric from the Gulf (Haerinck et al. 1993). Three vessels from Berenike are decorated in this manner (cf. Wheeler et al. 1946: Type 145; Begley 1996b: Motif 1), in one case diagonally slashed rather than thumbed (FIGURE 5). They occur in more than one fabric, some of which can be paralleled at Arikamedu, where the type is known from the 1st century BC into the medieval period. Since this is a common motif, detailed fabric descriptions are needed before a clear source area can be suggested for the Berenike sherds.

\section{Implications}

In his account of the trade between India and Egypt, the writer of the Periplus described contact with both the east and west coasts of India, but his emphasis suggested that the west coast was the more important of the two. The ports of Barbarikon and Barygaza in the northwest and the twin ports of Muziris/Nelkynda in the southwest on the Malabar coast are therefore integral to this discussion, but archaeological evidence from them is lacking. The Periplus also indicated that Western ships did not sail to the east of India, but instead exchanged goods indirectly via the west coast (Casson 1989: 15, 21-7; Ray 1995: 103-11; 1996:

3) either by coastal boats or overland.

Our lack of precision in sourcing the bulk of coarse wares excavated at Berenike is a major obstacle in interpreting trade routes between India and Egypt for this period. A more detailed approach to the study of pottery fabrics from
India, Egypt and sites between could address this issue. Scientific analysis of pottery in thin section undertaken by Krishnan (Krishnan \& Coningham 1995) has already demonstrated the potential of this approach for South Asian material, and analysis from additional sites may well allow distinction between fabrics whose aplastic inclusions consist primarily of feldspar and iron-rich minerals such as mica, pyroxenes and amphiboles.

Nevertheless, the distribution of some coarse and fineware Indian types found at Berenike, the rouletted dishes and bowls in Fine Ware 1 and paddle impressed sherds, is relevant. In India both have a heavy bias to the east coast and are apparently absent on the Malabar coast (Begley 1996a: 24), which may point to the east as a major source for goods to Egypt. Although hindered by the lack of any identified sites on the Malabar coast, and other dated sites from the Coromandel coast, Arikamedu is thus far the only site in southern India with Mediterranean finds known to have been active during the Augustan period, the context date for some of the table ware sherds found at Berenike. Arikamedu may therefore have been the point of departure for goods to Egypt (Begley \& Tomber: 170 ). If goods did indeed travel to the west coast via the east coast their route is as yet unclear, although the distribution of Rouletted ware and Russet-coated Painted ware may have implications for this. The latter is relatively common on the Malabar coast but virtually absent on the Coromandel (Begley 1983: 480; Ray 1995: 86) and its distribution - viewed in conjunction with the reversed pattern seen for rouletted ware - suggests that overland communication between the two coasts was indirect, perhaps through central centres such as Uraiyur.

The absence at Berenike of Red Polished ware, a type closely associated with northwest India, may or may not be significant in assessing the role of Barbarikon and Barygaza during this period. Here the botanical remains provide complimentary evidence which reinforces the association between Berenike and southwest India, for at Berenike there is an abundance of black pepper originating on the Malabar coast and an absence of long pepper from the region of Barygaza (Cappers 1998: 311; see also Kajale 1990).

To date, the identification of Indian and Indian-style wares in the Eastern Desert is re- 
stricted to the Red Sea ports of Berenike and Myos Hormos. Their absence at other sites in the Eastern Desert, at the imperial quarries of Mons Claudianus and Mons Porphyrites, as well as along the main coastal road terminating at Berenike, the Via Hadriana, strengthens their direct association with Indo-Roman trade and traders. Significantly, three Indian fineware sherds have recently been identified amongst Antiquarian finds from Coptos on the Nile (Elaigne 1999; Reinach 1912), the main transshipment point between the Red Sea and Alexandria for Indo-Roman trade.

The small quantity of finewares recovered at present, together with their restricted distribution, may indicate that they were brought by merchants or sailors for personal use, rather than for commercial purposes (Begley \& Tomber 1999: 168). This pattern is consistent with the known distribution of Wheeler Types 1 and 10 elsewhere for, although growing in numbers (Coningham \& Allchin 1995), apart from the eastern coast of India and its hinterland and the west coast of Sri Lanka where they occur in large quantities, sherds are rare from sites further inland. The greater quantity of coarse wares does not necessarily detract from this argument, for they too could have been brought as personal possessions and would support the existence of Indian merchant communities in Egypt, previously hinted at by the written evidence. If traders from Arikamedu were involved, epigraphic evidence from both Arikamedu, Berenike and Myos Hormos (Johnson 1979: plate

\section{References}

ARdikn, I.W. \& P. Bellwood, 1991. Sembiran: the beginnings of Indian contact with Bali, Antiquity 65: 221-31.

ARDIKA, I.W. P.S. BELLWOOD, R.A. EGGLETON \& D.J. ELLIS, 1993. A single source for South-Asian export quality rouletted ware?, Man and Environment 17.1: 101-9.

BEGLEY, V. 1983. Arikamedu reconsidered, American Journal of Archaeology 87: 461-81.

1988. Rouletted ware at Arikamedu: a new approach, American Journal of Archaeology 92; 427-40.

1996a. Changing perceptions of Arikamedu, in Begley et al.: $1-39$.

1996b. Pottery from the northern sector, 1989-92, in Begley et al.: 115-285.

BEGLEY, V. et al. 1996. The ancient port of Arikamedu. New excovations and researches $1989-92$ vol. 1. Pondicherry: École Française d'Extrême-Orient

BEGLEY, V. \& R.S. TOMBER. 1999. Indian pottery sherds from Berenike, in Sidebotham \& Wendrich (ed.): 161-81.

BüLOW-JACOBSEN, A., H. CUVIGNY \& J.L. FoujRNET. 1994. The identification of Myos Hormos. New papyrological evidence, Bulletin de l'Institut Française Archéologie Orientale $94: 27-38$ 27j; Mahadevan 1996: 207; Saloman 1991: 7346) would suggest that at least some of them were Tamil speakers (Begley \& Tomber 1999: 170).

At present, the evidence suggests that during the period in question south India was of main importance to the trade with Egypt. Both the west and east coasts appear to have played an important role but further evidence, from both India and Egypt, is needed to refine our understanding of the routes and mechanisms employed, and on-going work at both Berenike and Myos Hormos has much to contribute to this debate.

Acknowledgements. It will be clear that this note owes much to two Berenike reports written by Vimala Begley and myself, and had her health allowed she would have been an author here. It is, therefore, with great pleasure that I record my debt to her, although all errors remain my own. I am also grateful to Prof. V.N. Misra (Deccan College), Dr P.P. Dandawate (Deccan College Museum), Prof. V.H. Sonawane and Dr K. Krishnan (MS University of Baroda), and Mr K. Rajaram and Mrs N. Devi (Pondicherry Museum) for allowing me full access to their collections. I have benefitted greatly from discussions with many colleagues, particularly Dr R. Coningham (Bradford University), Dr S. Gupta (Allahabad Museum), Dr K. Krishnan (MS University of Baroda), Dr H. Schenk-Weisshaar (Bonn), Dr V. Selvakumar (Deccan College), and Prof. H. Wright (University of Michigan). FicukE 1 was prepared by Graham Reed. Finally, I thank Steve Sidebotham (University of Delaware) and Willeke Wendrich (University of California, Los Angeles) and their funding bodies, for inviting me to take part in the Berenike excavations, and David Peacock (University of Southampton), through whom I became involved in Egyptian archaeology, initially at Mons Claudianus and more recently Mons Porphyrites (with Valerie Maxfield, University of Exeter) and Quseir al-Qadim.

CAPPERS, R.T.J. 1996. Archaeobotanical remains, in Sidebotham \& Wendrich (ed.): 319-36.

1998. Archaeobotanical remains, in Sidebotham \& Wendrich (ed.): 289-330.

Casson, L. 1989. The Periplus Maris Erythraei. Text with introduction, translation and commentary. Princeton (NJ): Princeton University Press.

1991. Ancient naval technology and the route to India, in V. Begley \& R. De Puma (ed.), Rome and India: the ancient sea trade: 8-11. Madison (WI): University of Wisconsin Press.

CONINGHAM, R.A.E. \& F.R. ALLCHIN. 1995. The rise of cities in Sri Lanka, in F.R. Allchin (ed,), The archaeology of Early Historic South Asia: 152-84. Cambridge: Cambridge University Press.

ELAIGNE, S. 1999. Northern Black Polished Ware from Coptos, Poster presented at the European Assoriation of South Asian Archaeologists, Leiden 1999

FRANCIS, P.. IR. In press. The beads, in Sidebotham \& Wendrich (ed.).

FUKS, A. 1951. Notes on the archive of Nicanor, Journal of Juristic Papyrology 5: 207-16. 
GOGTE, V.D. 1997. The Chandraketugarh-Tamluk region of Bengal: source of the early historic rouletted ware from India and Southeast Asia, Man and Environment 22.1: 69-85.

HAERINCK, E., C.S. PhILLIFS, D.T. POTTS \& K.G. STEVENS. 1993. Ed-Dur, Umm al-Qaiwain (U.A.E.), in W. Finkbeiner (ed.), Materialien zur Archäologie der Seleukiden - und Patherzeit im sudlichen Babylonien und im Golfgebeit: 183-93. Tübingen: DAI Abteilung Baghdad.

JOHNSON, W.R, 1979. Roman pottery, in D.S. Whitcomb \& J.H. Johnson, Quseir al-Qadim 1978. Preliminary report: 67103. Cairo: American Research Center in Egypt.

KAIALE, M.D. 1990. Ancient plant economy from excavations at Mantai, district Mannar north-west Sri Lanka, Ancient Ceylon 11: 263-6.

KRISHNAN, K. \& R.A.E. CONINGHAM. 1995. Microstructural analysis of samples of rouletted ware and associated pottery from Anuradhapura, Sri Lanka, South Asian Archaeology 2: 925-37.

Mahadevan, 1. 1996. Tamil-Brahmi graffito, in Sidebotham \& Wendrich (ed.): 205-8.

PEACOCK, D.P.S. 1993. The site of Myos Hormos: a view from space, Journal of Roman Archaeology 6: 226-32.

RAY, H.P. 1995. A resurvey of Roman contacts with the east, in M.-F. Boussac \& J.-F. Salles (ed.), Athens, Aden, Arikamedu. Essays on the interrelations between India, Arabia and the Eastern Mediterranean: 97-114. New Delhi: Manohar.

1996. Maritime archaeology of the Indian Ocean: an overview, in H.P. Ray \& J.-F. Salles (ed.), Tradition and archaeology. Early maritime confacts in the Indian Ocean: 1-10. New Delhi: Manohar.

REINACH, A.J. 1912. Rapport sur les fouilles de Koptos, Bulletin Société Française des Fouilles Archéologiques 1912: 81.

SALOMAN, R. 1991. Epigraphic remains of Indian traders in Egypt, Journal of the American Oriental Society 111(4): 731-6.

SAR JSWATI, B. \& N.K. BEHURA. 1966. Pottery techniques in peasant India. Calcutta: Anthropological Survey of India.

SEDOV, A.V. 1992. New archaeological and epigraphical material from Qana' (South Arabia), Arabian Archaeology and Epigraphy 3/2: 110-37.

1996. Qana' (Yemen) and the Indian Ocean. The archaeological evidence, in H.P. Ray \& J.-F. Salles (ed.), Tradition and archaeology. Early maritime contacts in the Indian Ocean: 13-32. New Delhi: Manohar.
SElvaKumar, V. in press. Appendix B: impressed sherds, in V. Begley et al., The ancient port of Arikamedu. New excavations and researches 1989-92 vol 2. Pondicherry: École Française d'Extrême-Orient.

Sidebotham, S.E \& W.Z. WENDRICH (ed.) 1995. Berenike 'g4. Preliminary report of the excavations at Berenike (Egyptian Red Sea coast) and the survey of the Eastern Desert. Leiden: Centre of Non-Western Studies.

1996. Berenike'95. Preliminary report of the excavations at Berenike (Egyptian Red Sea coast) and the survey of the Eastern Desert. Leiden: Centre of Non-Western Studies.

1998. Berenike '96. Report of the excavations at Berenike (Egyptian Red Sea coast) and the survey of the Eastern Desert. Leiden: Centre of Non-Western Studies.

1999. Berenike' '97. Report of the 1997 excavations at Berenike and the survey of the Egyptian Eastern Desert, including excavations at Shenshef. Leiden: Centre of Non-Western Studies.

In press. Berenike '98. Report of the 1998 excavations at Berenike and the survey of the Egyptian Eastern Desert, including excavations at Kalalat. Leiden: Centre of NonWestern Studies.

Silv , R. 1985. Mantai — a second Arikamedu?, Antiquity 59: 46-7.

SMITH, M.C. \& H.T. WRIGHT. 1988. The ceramics from Ras Hafun in Somalia: notes on a classical maritime site, Azania 23: 115-40.

TAIT, J.G. (ed.). 1930-64. Greek ostraca in the Bodleian Library at Oxford and various other collections. London: Egypt Exploration Fund.

TOMBER, R.S. In press. The pottery, in D.P.S. Peacock, L. Bhue, N. Bradford \& S. Moser, Myos Hormos - Quseir al-Qadim: A Roman and Islamic port site on the Red Sea Coast of Egypt. Interim Report, 2000. Southampton: University of Southampton.

TOMBER, R.S. \& V. BEGLEY. In press. Indian pottery sherds from Berenike, in Sidebotham \& Wendrich (ed.)

VERMEEREN, C.E. 1998. Wood and charcoal, in Sidebotham \& Wendrich (ed.): 331-48.

WHEELER, R.E.M., A. GHOSH \& KRISHNA DEVA. 1946. Arikamedu, an Indo-Roman trading-station on the east coast of India, Ancient India 2: 17--125.

WILD, J.P. \& F. WILD. In press. Textiles, in Sidebotham \& Wendrich (ed.). 